\title{
The civil procedure principles as the essential basis for undisputed enforcement of obligations
}

\author{
Andris Pesudovs \\ Rīga Stradingš University, Latvia
}

\begin{abstract}
Not always are a legal transaction and the legal consequences thereof limited to complete and voluntary fulfilment of the mutual obligations of the parties. In cases when a commitment has not been fulfilled, there is an option for a creditor to request for judicial protection in order to prove substantiality of his claim and to receive confirmation to his right to recover the debt in a form of court judgment. However, in the civil legal relationship such impairment of a right is possible which exists outside the dispute regarding the right. A debtor fails fulfilling his obligation and not denies doing it. In such circumstances, notwithstanding recognition of the debt, in order to achieve compulsory execution of the obligation, a document to be enforced is also needed. Provided the type of transaction allows establishing of such type of legal consequences, simplified procedural arrangements may be applied, and restricted principle of contest may result in the possibilities of procedural economy being exercised. Admissibility of such procedural possibility also inevitably activates the discussion regarding what the preconditions of the simplified procedure are and how the simplified procedure of establishing the debtor's obligation can be consistent with protection of his rights. The article focuses on the procedural legal principles, which are involved in the alternative to claim proceedings action of the expedited proceedings and the mutual coherency thereof. Attention is also paid to the form of the transaction and significance thereof in the simplified proceedings.
\end{abstract}

Key words: principles of disposition, adversarial principle, procedural economy, protection of a debtor's rights.

\section{Introduction}

In the civil procedural law, certain alterative to the claim proceeding exists - a simplified, expedited possibility to establish obligations. The simplified proceedings, being alike in their procedural features and grounds of action, are widespread in various countries. The civil procedure law of Germany, for instance, provides for Proceedings of Acts and Promissory Notes (Urkunden - und Wechselprozess), similar procedural arrangements in Russia are named proceedings of judicial order (приказное производство), in the Civil Procedure Law of Latvia (hereinafter - CPL) undisputed compulsory enforcement of obligations (hereinafter-UCEO) is incorporated. The substance of the expedited proceedings is similar. The court judgement establishes a debtor's obligation to fulfil a commitment, based exclusively on the offered by a creditor's arguments without hearing the debtor's opinion. The judgement is given in the circumstances when the debtor has limited possibility to influence the confidence of the court regarding the actual circumstances of the case; in regard to the debtor the law allows limited expression of the adversarial principle. In Latvia, interpretation of Section 400 Paragraph One Clause 1 of CPL has proven pending - UCEO is permitted 
pursuant to agreements regarding obligations which are secured with a public mortgage or commercial pledge. In this regard the Supreme Court of the Republic of Latvia (hereinafter AT) has also provided its opinion, necessarily linking protection of a debtor's interests with public mortgage only, and only considers the simplified proceedings to expedited sale of the mortgage. However, UCEO as an alternative to the claim proceedings in the specified by CPL events, and a possibility to contest a given in an expedited proceeding judgement indicates that the form of a transaction is not sufficient ground to justify restriction of the adversarial principle.

The abovementioned procedural rule includes concepts of substantive law, but does this rule therefore only provide for proceeding for selling the pledge or the selling the pledge per se (directing recovery against the pledged property) ensures a debtor or pledge's rights. As H. Kelsen, German law scientist, has indicated, "Law is not, as it is sometimes said, a rule. It is a set of rules having the kind of unity we understand by a system. It is impossible to grasp the nature of law if we limit our attention to the single isolated rule. The relations that link together the particular rules of a legal order are also essential to the nature of law. Only on the basis of a clear comprehension of those relations constituting the legal order can the nature of law be fully understood" [1]. In order to achieve an objective answer regarding reading of Section 400 Paragraph One Clause 1 of CPL, systemic links of this legal norm to other elements of CPL must be established. References for establishing such coherences are to be found in the mutual relationship between the principle of disposition and the adversarial principle. Whereas concerted operation of these principles allow acquiring outcome of more effective application of legal norms by letting the procedural economy manifest itself.

\section{The principle of disposition and the adversarial principle}

Section 400 and Chapter 50 of CPL in total provide for an exception of the overall procedure of settling civil disputes. UCEO is a facultative and peculiar institute in the civil procedure, hence the incorporated in its regulation requirements are specifically essential for existence of this institute, and the legal norms are not to be interpreted in an extended manner. Consequently, the exceptional arrangements where a judge's judgement comes in force immediately cannot be turned into general provision as there are disputes of various levels of difficulty [2]. In such a manner, by opposing the UCEO to the claim proceedings, the commentaries to CPL characterise the alternative procedural arrangements; simultaneously the 2010 summary of AT regarding the judicial practice of UCEO is mentioned as a significant source for substantiating the opinion.

AT has given the following definition, "UCEO is a separate type of proceedings with its own peculiarities and provisions, which are exclusively characteristic to this type of proceedings. It is simplified and expedited proceeding where no debtor's objections are permissible. Application is decided in a written procedure on the basis of nothing but the submitted by a creditor documents that are provided in Section 404 of the Civil Procedure (hereinafter - CPL)" [3]. In essence, the summary of the AT practice has focussed the main conclusions of applying the effectual Section 400 Paragraph One Clause 1 of CPL by which the court judgements are grounded and which support the dominating in the national law science opinion on UCEO.

Both the case-law and the national law science unequivocally perceive UCEO as an independent subclass of CPL - independent, separate type of the civil procedural arrangement. Such an arrangement is attributed by peculiar, exceptional nature as unlike the general civil procedural arrangement (claim proceedings) no adversarial principle is allowed. Furthermore, the restricted civil procedural status of a debtor is accented by attributing to 
him/her the role of an observer while a creditor exercises the advantages of the expedited procedure.

The characteristic civil procedural features of the UCEO law institute are concisely incorporated in Section 400 Paragraph One Clause 1 of CPL (the corresponding to UCEO form of commitment within the framework of the problems of the research), Section 404 Paragraph One and 405 Paragraph One to Three of CPL: UCEO is permitted pursuant to agreements regarding obligations which are secured with a public mortgage or a commercial pledge; in an application there shall be set out the obligations and the documents pursuant to which the creditor requests undisputed enforcement; the judge, having examined the validity of the submitted application and having found that it is to be allowed, shall take a decision pursuant to which the obligation to be enforced, and the extent to which it should be forced, in accordance with undisputed compulsory procedure, are determined; the judge's decision shall enter into effect without delay, and it shall have the effect of an enforcement document. The decision shall be enforced in accordance with the provisions regarding the enforcement of judgments [4]. Reflected in such an amount part of UCEO in regard of the conditions for taking a judgement outside the adversarial principle also conform with the opinion expressed in the commentaries to CPL; that said, admissibility of existence of the law institute and objective scientifically theoretical thereof is not practicable outside the procedural element of disputing the judge's decision according the UCEO procedure.

The foundation of a debtor's rights protection are provided in Section 406 Paragraph One and Three of CPL. If a debtor is of the opinion that the claim of the creditor is, on the merits, unfounded he or she may, within six months from the date when the true copy of the decision is sent, bring an action against the creditor to dispute the claim. The action shall be brought in such court in accordance with the general procedures. In bringing action, the debtor may request a stay of the undisputed enforcement, but if the creditor has already received satisfaction through such process - may petition to ensure the action [4].

From the aspect of legitimacy, only the formally provided in the law procedural arrangement the primary objective of which would be validity of the legal norm, would not be compatible with justification of the necessity of the state power. Legitimacy or recognition of the law, acceptance in the society is to be treated as an indication of the substance of the positive law. The legal norms only become as such when objective recognition is received by the society to utilise them as the founding grounds for rights and obligations of subjects. Outside the concept of legitimacy of the law it is not possible to answer the question regarding how the normative arrangements are developed which owns the possibility to restrict the individuals' will and determine the direction of their actions. Thereby not the very possibility to constrain but, first of all, the authority of the legal norms, recognition thereof ensure their action, and legitimacy is to be seen as the quality characterising and cognizing the ontology of the legal norms [5]. An expedited and simplified procedural arrangement is not an end in itself, but it is procedural means by the assistance of which the matters within the dispute are segregated from the others on the basis of the possibility of choice granted to the rightholders in the law. "As the law can only be considered within the context of the public authority, the core of the rule of the law is justification of the authority of the state and the law from which the efficiency or usefulness of the law follows" [6]. The provided in Section 406 Paragraph One Clause 1 of CPL debtor's rights to dispute a creditor's claim as substantiation for conformity of UCEO to the Constitutional Law of the Republic of Latvia has been also mentioned in the adjudication of the Constitutional Court of the Republic of Latvia, "Thereby the contested norms of Section 405 of CPL in the context of the provided in Section 406 procedure of contesting the undisputed enforcement of obligations ensure the incorporated in Section 92 of the Constitutional Law element of a equitable court procedure rights of appeal" [7]. Thereby the coherence between the granted in Section 405 of CPL to 
the UCEO judgement status of a document to be executed, which in regard of compulsory enforcement is comparable to the adjudication, and the procedural rights to contest such a judgment is evidently manifested.

Furthermore, the opinion of the Constitutional Court of the Republic of Latvia (hereinafter - Constitutional Court) in this matter fully concords with the opinion of the Ombudsman regarding protection of the debtor's rights that he has expressed in the indicated adjudication. "Referring to the case-law of the European Court of the Human Rights, the Ombudsman notes that the state must ensure protection of the principal rights of a person as effective as it is practicable, and the rights to address the court are not absolute, therefore they may be reasonably restricted. Section 406 of CPL is supposed to guarantee to a debtor rights to institute a claim for overturn or backward execution, therefore there are no grounds to state that CPL prevents a debtor from protecting his rights by appealing the judge's decision. The Ombudsman concludes that Section 400 Paragraph One Clause 1 and Section 405 Paragraph One and Three of CPL guarantees compliance with the right to fair trial and conforms to Section 92 of the Constitutional Law" [7]. Within the context of the research, the reference made by the Ombudsman to Section 406 of CPL as a procedural guarantee for protection of a debtor's rights is to be taken into consideration.

The stated conclusions of the Constitutional Court and the Ombudsman's opinion directly refer to the link between UCEO and the claim proceedings. Whereas existence of such a link per se displays inevitability of the principle of disposition as civil procedural theoretical necessity. The concept of disposition has been often used along with the adversarial principle. If the adversarial principle provides for the activity of the participants in a proceeding to ground (prove) existence or non-existence of facts, dispositive principle is characterised by a person's freedom of choice including also waiving the rights, not to use them, which on its turn simultaneously may be deemed confirmation of relevant legal consequences having occurred.

The law science confirms that those are the principle of disposition and the adversarial principle that most evidently manifest the specific source of the civil proceeding. Dispositive principle characterises the freedom of the mutual relationship of the interconnected parties the right-holders the existing between whom disputable, indefinite civil legal relationship in the circumstances of a civil contest have become a subject matter of civil proceedings. Disponere is a Latin term meaning - act, arrange, place in particular order. According to this traditional thesis, the party granted with subjective rights is also entitled to operate with these rights during the proceeding. Alike contest, dispositive principle is ontologically related to the objectives, substance and form of the civil procedural arrangements. As the initial foundation of the civil proceedings, disposition pertains to all the types of legal proceedings and the stages of proceeding [8]. The role of dispositive principle is specifically accented in determining the progress of a proceeding and in practicable, comprehensive defence [9]. Completion of the civil procedural arrangement with expedited, alternative to the claim proceedings procedural forms is to be directly evaluated as manifestation of the principle of disposition of a creditor's act with a claim. Furthermore, dispositive principle is to be characterised as a creditor's option to choose a procedural arrangement (alternative expedited proceeding) and the grounds of a debtor's choice to consider the established in the judgment consequences as being correct or to dispute them according to the provided in Section 406 of CPL procedure.

“A creditor's claim grants him with a right to accept fulfilment of a debtor's commitment as well as a right to keep what s/he has received in the result of fulfilment the commitment. Besides, a creditor is entitled to operate with his/her claim, for instance, to withdraw the claim (CL, Section 1863), cede it (CL, Section 1793), propose it for set-off (CL, Section 1852), and pledge it (CL, Section 1294)" [10]. The material origin of disposition is also evident in this 
opinion expressed by Latvian law scientist E. Kalniņš regarding a creditor's possibilities of action with a claim, and simultaneously it also points to disposition as procedural grounds as by such type of rights a creditor may also act over the progress of a civil procedure by appropriately affecting application of the procedural legal norms.

The origins of more precise defining the content of the principles of disposition and adversarial action are related to the Austrian and German science of procedural law. Austrian scientist Canstein provided that it is the term Dispositionsmaxime (dispositive foundation, origin) that expresses the idea of the parties' free operation with their civil procedural rights (die Verzichtbarkeit der Parteienrechte im Zivilprozesse) [11]. In Canstein's opinion, the parties' options of choice in a proceeding include: 1) claim rights (material disposition), external progress of the proceeding (formal disposition) and the actual material (contest). Taking the said into consideration, the scientist divided the parties' rights of choice into three parts: 1 ) the right to initiate and preserve the external progress of the proceeding (Prozessenbetrieb); the parties' right to choose to operate with their claims (Dispositionsmaxime) and the right to operate with the actual and proving material (Verhandlungsmaxime) [11]. On the basis on the proposed by Canstein thesis, so called leading doctrine of the dispositive principle as formulated in the procedural science, which expressed itself in the following way.

The subjective civil rights have inherent quality that expresses itself in the freedom of use thereof. The civil rights can be acquired, forwarded, alienated. If the rights are offended, the rightful person has the freedom of choice to protect or not to protect those. The said quality of the civil rights allows to draw conclusion regarding the proceeding: in case the entitled with subjective rights empowered person can freely operate with them, alienate them in the form of compensation or without compensation, waive them etc., the said person may stand the offence thereof or apply to the courts for safeguard, but nobody can force to apply to the courts in compulsory manner - nemo invitus agere cogitur; no civil proceedings may be commenced by the initiative of the court or any other person without a plaintiff's claim: nemo judec sine actore, kein Klager kein Richter; the task of the court is restricted to examination of the case within the limits of the claim; the court does not exceed the limits of the claim: ne eat judex ultra petita partium. Not only does the principle of disposition manifest itself in the right of free choice to apply to the courts, but embraces also the parties' rights in the proceeding. Thereby the following considerations are inevitable: a plaintiff cannot be restricted in his/her right to waive the claim, to reconcile with the opponent, to deem his/her objections substantiated; the empowered person must be granted with the rights to dispute the opponent's objections or agree thereto, to submit or not to submit evidence in favour of his/her claim, to dispute the judgement of the court and waive such rights etc [9]. The said in its aggregation points to the restricted competency of the court in action with the parties' procedural rights, and complete autonomy of the parties regarding the material rights in the proceeding.

The provided theoretical considerations of the dispositive principle have immediately manifested themselves in the civil procedural legal acts. Section 58 of the Civil Procedure Law of Switzerland (Dispositions - und Offizialgrundsatz) provides dependence of the limits of the court competency on the parties' freedom of utilisation of their rights: the court satisfies the claim without exceeding the claimed and not in less amount than the other party has admitted; the court operation is restricted by the request of the empowered party [12]. Regardless the fact that CPL does not incorporate any specific definition, the dispositive principle manifests itself in a focussed way in the procedural norms of the national law concerning the rights and obligations of parties and third persons.

Pursuant Section 74 of CPL, the parties have rights: to submit evidence; to participate in examination of evidence; to submit petitions; to raise objections against requests, arguments 
and considerations of other participants in the case; to appeal court judgments and decisions. Further, a plaintiff is entitled: to withdraw their claims partly or fully; to reduce the amount of their claims; in writing, to amend the basis or the subject-matter of their action or to increase the amount claimed. A defendant is entitled to admit a claim fully or partly, or to bring a counterclaim [4]. The examined theoretical foundation of the dispositive principle extensively discloses the meaning of Section 406 of CPL, the content of the legal norms thereof which hides behind its formally expressed rights to dispute the judgement. The legal norm contains both a debtor's right to contest the judgement and deeming the claim an independent expression of disposition if the provided civil procedural rights are not exercised.

The material grounds of an overturn claim are based on the essence of the subjective private law. The subjective law is the legal authority intended to realize a right-holder's interests, which exists on the basis of objective law and exercising of which depends on the personal will of the holder [13]. Utilisation of the subjective law is the main legal instrument in realisation of the private autonomy of the civil law subjects [14]. Private autonomy means a possibility given by the legal system to a person to rule one's own legal relationship and relationships with the fellow-citizens by the means of the realised by oneself legal act (legal transaction). Private autonomy is the central concept of the private law [15]. In order to realise one's interests, the right-holder must express relevant will. By realising the subjective rights, the right-holder may freely realise his/her will provided this occurs within the limits laid down in the objective law [16]. The legal authority that is incorporated in the attributed individual's subjective rights is not unrestricted. The attributed to the right-holder legal authority is not absolute but controlled by the law authorisation of action [17]. The law provided the necessary restrictions and prohibitions so that realisation of the subjective rights does not infringe the legal order or the grounded interests of the other participants of the civil circulation [14]. The subjective rights are the consequences caused by application of the general legal norms (objective norms) in regard of some particular person [15]. The relationship of the subjective rights and disposition have been characterised in a scientific study of the civil procedural arrangements in Bulgaria, "Disposition is a principle permanently inherent to the civil proceeding. Protection of the offended rights follows from the will of a person entitled to request for such protection. This principle originates from the autonomy of the will in the private law and the functional link of the material private law and the civil proceeding. This link demonstrates the relationship of the protective nature of the proceeding and the material law" [18]. The said functional link is also realised in the event of Section 406 of CPL. A debtor, when realising coherent to him/her autonomy of the will in the private law, decides him/herself regarding offence of his/her rights and necessity of protection of thereby offended rights.

Thereby, should a creditor have violated the limits of his/her private autonomy by indicating in the application a debtor's commitments which do not conform to his/her obligation of the subjective rights or the creditor's conduct is not compatible with compliance to the requirements of the objective rights, the debtor is entitled to bring action against the creditor by disputing the established in the decision creditor's claim by its substance, which, on its own turn, is a necessary element of the debtor's private autonomy (material disposition). Furthermore, noteworthy is not only the option of appeal per se but also the provided in Section 406(3) stay of enforcement of the decision, which restricts the consequences of the disputed judgement. After the case being instituted, a debtor acquires the provided over the progress of the proceeding in Section 74 of CPL rights in establishing the actual circumstances of the case and qualifying the legal consequences thereof within the limits of his/her legal status and private autonomy to operate with the material and procedural 
rights (formal disposition), as well as participate in submitting evidence and examination of the evidence (contest). As pointed out by J. Rozenfelds, a debtor has no other way how to defend him/herself against the UCEO arrangement than by counterclaim regarding the fact that the fulfilment of the commitment has not matured yet, that the commitment is invalid and alike [19]. It is possible that misspelling has occurred, yet the essence of the overturn claim has been provided correctly in principle.

The connection of UCEO and the claim proceedings, which mainly originates owing to mediation of Section 406 of CPL, on March 1, 2012 was established also by the AT Senate in its decision in case No SKC - 1133/2012 - the provided in Section 406(1) of the Civil Procedure Law period of six month for instituting an overturn claim is supposed to be a provided in the law procedural term, which absolutely must be observed just like other terms laid down in the Civil Procedure Law; actually the provided in this norm requirement is a procedural instrument of appeal [20]. Incomplete evaluation of the rights to contest undisputed judgement by a debtor exercising his rights within the granted by the law disposition may be the reason for the conviction of attachment of the issue of dispute solely to the value of the pledge (the remnant of the debt after the pledge being sold) not to the compliance of the transferred to UCEO commitment to the creditor's claim [21]. Considering the analysed prevalence of the elements of disposition and contest also regarding UCEO, it would not be sufficient to restrict the content of the indicated institute of law by nothing but simplicity of the proceeding, rapidity and its nature of exception. By including therein the element of the parties' private autonomy, the definition of such expedited proceeding can be established. UCEO is a civil procedural possibility to take a decision of the power of a document to be executed outside examination of the evidence within the adversarial principle when the offence caused to a creditor and a relevant debtor's obligation by substance are established in the form of formally restricted actual substances in regard to limited by CPL scope of civil relationship, while there simultaneously exist a debtor's rights to contest such a judgement, stay of undisputed enforcement and examination of the substantiating the undisputed enforcement facts according to the procedure of the claim proceedings.

According to R. Saulite, Senator, in order to compel a commitment according to the procedure of undisputed enforcement, there should be a positive confidence that such commitment really exists. That is why the law has determined the events when SBBPI is admissible [22]. The idea of "positive confidence" has been also adopted in applying the norms of the UCEO institute of law. In its judgement of January 9, 2008 in case No SPC-2 the AT Senate provides, "In accordance with Section 400(1) of CPL, in order to transfer a commitment for undisputed enforcement, positive confidence must exist that such a commitment really exist. This legal norm has determined the event when such public credibility of a commitment exists and when undisputed enforcement of a commitment is possible" [21]. The thesis is also incorporated in the aggregation of the case-law of AT: the ground for undisputed enforcement is always a public deed, which creates credibility of existence of the respective commitment; an essential requirement is inadmissibility of a dispute regarding the existence of a commitment and credibility of a commitment, which is ensured by existence of a public deed [3]. Confidence in sufficiently positive existence of a commitment is also incorporated in the commentaries of CPL, "The section to be commented envelopes such kind of commitment where a creditor need not request to establish existence of the commitment as it has been sufficiently established by documents of high level of credibility" [2]. However it must not be forgotten that entering a pledge right in a public registry is no more than an element of the form, which cannot be equated and perceived as equal to the very pledge right and the secured thereby commitment. Certain level of credibility 
do exist, and it has procedural significance, still the very form of a public pledge is not a proof equal to the very fact of existence of a debtor's commitment in the provided in the application amount.

Section 1281 of the Civil Law (hereinafter - CL) also points to the validity of such a conclusion. A mortgage may be established as security for claims which may arise in the future from credit available to debtors (credit mortgage). In registering such mortgage in the Land Register, the amount of the credit available shall be indicated, in regard to which extent the credit mortgage also has priority rights from the time it is registered in the Land Register [23]. According to V. Bukovskis, credit mortgages do not differ from the regular mortgage. Corroboration of a credit mortgage in the Land Register provides no answer to the question whether the claim has really occurred and in what amount [24]. J. Rozenfelds also confirms the said - in terms of time a mortgage as security originates before occurrence of the securable claim (lending money etc.), but it ceases its existence after expiry of the securable claim [19]. G. Višņakova also has addressed this circumstance in this case a pledge contract secures not the already existing legal relationship, but the claim which may occur in the future [25]. The said conclusion are generally confirmed by such a realisation - the legal consequences of mortgage differ from the consequences of a pledge right in the facilitated possibility of proof, the related to it expedited manner of recovery and the advantage in contest. In the aspect of the material law, this proceeding allows the same objections and legal means of dispute as any other proceeding regarding a pledge right [26]. CL also provides direct references to the level of credibility of the entries in the Land Register. Pursuant the second sentence of Section 1480 of CL, corroboration does not rectify internal defects of the transaction, and a deed which is not in force according to its substance does not thereby acquire any legal effect. Similarly, corroboration shall also not affect the rights of a third person previously registered in the Land Register [27]. A registered in the Land Register mortgage may be contested in a claim proceeding, and a mortgage may be deemed invalid due to internal deficiencies of the transaction [25]. Taking into account Section 7(1) of the Law on the Commercial Pledge, all the said about mortgage in this regard may be also referred to a commercial pledge - any claim may be secured by a commercial pledge, either one already existing or one which may occur in the future from the established commitment [28]. Mortgage or commercial pledge is nothing but the ground for reasonable assumption regarding possibility of existence of commitment in the provided by a creditor amount, and without the considered debtor's dispositive option of choice provides no complete answer regarding the existence of his/her commitment.

The civil procedural arrangements of Germany and Russia have deleted the criterions of the public credibility; the main condition is the written form thereof. According to Section 592 of the German civil law, a claim must be grounded by written documents [29]. If the court deems a claim substantiated by documentary evidence (outside the requirement of necessary public credibility thereof), the court decides to satisfy the claim in the amount which has been proven by the documents [30]. It is also additionally confirmed by the commentaries to the law - a claim may be referred to a written proceeding if all the needed for substantiation thereof facts are documentary evidence [31]. Similarly, Section 121 of the Russian civil procedure code provides for application of приказное производствоіn regard to claims that are substantiated both by notary confirmed contracts, protested bills, and the contracts, where written form has been followed without special confirmation [32]. In such context, the deciding role of dispositive principle is evident in the possibility to direct the progress of the proceeding into the procedural arrangement of a claim proceeding. The form of a public pledge as the possibility to facilitate proving in the proceedings alternative to the claim proceedings are to be attributed a secondary significance. 


\section{Procedural economy and effectiveness}

The dispositive origin facilitates optimal settlement of initiatives and activities in a civil procedure among the parties and the court [9]. Regardless the necessity for a judge to conduct the proceeding in a controlled manner, the direction of this dynamics is related to and to certain extent subjected to the dispositive foundation. This is the aspect worth exercising for analysing the UCEO functions, the significance thereof and the limits or possibilities to affect the procedural arrangements.

The civil procedural arrangements develop mutually coherent system of the procedural principles. Such a system testifies for certain independence of the principles but not complete autonomy thereof. Each principle as an element of the system of principles characterises the civil procedural arrangements in its totality and each law institute separately. It is possible that such principles exist which are specifically evidently manifested in some particular institute of the civil procedural law [8]. The objective of UCEO as an institute of the procedural law is to realise the procedural economy. The significance of such expedited procedure of simplified examination of cases has been also established by the Constitutional Court rapid examination of cases, decrease of the load on the courts and protection of the persons' rights [7]. The court derives its conclusion from the previously made statement - the objective to ensure more rapid and efficient examination by reducing loads of the courts may be deemed legitimate [33]. In this regard, it is essential to highlight the significance of the objective of UCEO in the legitimate existence of the expedited arrangements of proceedings. If the previously established provided in Section 406 of CPL expression of a debtor's disposition creates grounds for legitimate action of UCEO, the procedural economy as a legitimate objective of this procedural institute creates a necessary precondition for justified restriction of a debtor's disposition until judgement is given in an expedited proceeding. Consequently, the procedural economy is to be regarded not only as an option offered by UCEO, but as a necessary requirement to the result of applying the law institute, which simultaneously facilitates: rapid examination of cases, decreased load of the courts, and protection of persons' rights.

Specifically with achieving such objectives, by preventing excessive protraction of proceedings, the tasks of the administration of the court system are related in majority of the countries [34]. In the foundation of the said legitimacy lie the existing in the state and the society socioeconomic processes, which by creating threat to overload of the courts have been the decisive ones in elaboration and development of a procedural law institute of undisputed enforcement. It may be one of the ways how low-based states, being driven by a uniform task, have manifest their efforts in order to avoid excessively expensive and protracted proceedings of dispute examination, when the efficiency of the law diminishes and injustice and arbitrariness occur as the result of the said processes [35]. An expedited proceeding has proven to be significant not only in the law of the continental Europe. Initially, in examination of cases, the Common-law system provided for necessity of a defendant to be present in the court hearing so that the case may be adjudicated and a decision taken. In this regard, various sanctions were elaborated in the traditional systems in order to force a defendant to attend. In contract to such arrangements, nowadays, non-attendance of a defendant per se or failure to defend one's interests in another way grants the court with power to take an undisputed decision "default judgment". For instance, refusal to respond in relation to the instituted claims may result in taking an undisputed decision [36]. Realisation of such considerations can be established in more recent legal acts. For instance, in the scientific legal literature regarding the basic principles of the English civil procedural arrangements, the principle of accelerated judgement was ranked above the acknowledged in our CPL principle 
of immediate and oral proceedings. Taking into consideration admissibility of expedited proceedings, in the result of recognition or non-contesting a claim, majority of the judgements are given outside a court hearing [37]. Similarly, in USA, an undisputed proceeding is granted with significance equal to the law principle. Such procedure is reasonably considered not disfavoured procedural shortcut but inalienable element of the federal law, which helps ensure justice, offers possibility of rapid and inexpensive decision of any claim [38].

In the events when in regard of the parties' dispute nothing but the result of solving the discords is to established, the civil proceedings may prove unnecessary [35]. Concerning the progress of the objective of UCEO as an institute of law to make the process more efficient, the mechanism of the procedural economy of this legal norm is characterised by a possibility to segregate and examine in a simplified proceeding the cases where no dispute exists. Such aspect presents the entire essence of improving the efficiency of the court activity and the potential as well - not to examine in the arrangement of court proceedings the cases where no dispute exists regarding the rights. The result of the procedural economy is every undisputed judgement of UCEO by assistance of which the matter of rights has been decided outside the claim proceeding. The significance of UCEO or the civil procedural value thereof manifest itself in granting an option of choice, by ensuring availability of appropriate procedural institute. It is expression of the parties' self-regulation within the principle of disposition.

Historically the first, universal by its nature, the claim proceedings occur as the form of the existence of civil procedure in the Roman law. The arrangements of the undisputed proceedings have the same genetic root [8]. This remark is essential as it indicates the close link of UCEO or other expedited proceedings to the same principles of the procedural law to which the claim proceedings are subjected. The expedited proceeding is not affected by the specific character of the matter of law to be decided as it is, for instance, in the arrangements of special trial procedures. Simplified proceedings are based on rational considerations and the procedural economy also justifies such rationalism, which provided possibility to utilise the resources of the judicial system in a more efficient way.

\section{Conclusions}

1. Legitimacy of the simplified proceeding (UCEO), the legal justification thereof is the provided in the procedural law debtor's option to dispute the court judgement by directing the matter of the validity of a creditor's claim to be examined in the claim proceedings, when, by realising the adversarial principle, comprehensive verification of the facts is practicable. Such option of dispute has two functions. First, protection of debtor's rights. Second, recognition of validity of a creditor's claim and a court judgment, if the right of appeal is not exercised.

2. The form of a transaction cannot be equated to the facts. The indicated in the application debtor's commitment, regardless the public form of the transaction (notary deed, bill, mortgage), is nothing but a creditor's statement. The significance of the abovementioned forms manifests itself in the increased credibility and thereby facilitates proving. The special public form of a transaction has significance of procedural means; it does not ensure legitimacy of the proceeding and protection of a debtor's rights. The secondary significance of a public form is also pointed out in the examples of Germany and Russia of limiting the requirement of publicity of the documents.

3. The operation of simplified proceedings basically involves three principles of the procedural law: the principle of disposition, adversarial principle and procedural economy. Coordinated operation of these principles manifests itself in the following manner: a debtor, by realising his dispositive choice, does not contest an undisputed 
judgment; legitimate justification is created to restrict the adversarial principle (debtor's refusal of contest); thereby the procedural economy is achieved (the legal consequences are established without applying the claim proceedings and the relevant thereof verification of evidence). Considering the established coherence of the procedural principles, similar procedural elements are to be utilised in the formulae of undisputed proceedings: recognition of a claim, non-presenting objections, and non-contesting.

4. The simplified proceeding is not the necessity caused by any peculiarity of the legal relationship to be judged. Development and existence of simplified proceedings can be explained by rational considerations regarding the economy of the judicial system resources. Therefore realisation of the procedural economy is an indispensable requirement (in addition to a debtor's right of contest) for legitimate operation of such proceedings and justification of the necessity thereof.

5. The displayed coherence of the procedural principles and ability thereof to ensure protection of a debtor's rights provide grounds for neutrality of the simplified proceedings in regard to the publicly credible forms of transactions. Such possibility allows waiving the claim pursuant a specifically confirmed document substantiating the transaction and thereby widening the scope of the events admissible for examination according to the undisputed procedure. It can be achieved by balancing a creditor's rights to a simplified proceeding and a debtor's option of the dispositive choice.

6. The established connection of the transferred to UCEO commitments and a debtor's rights to fully contest a creditor's claim can also be referred to Section 400 Paragraph One Clause 1 of CPL. Further, if a debtor has not exercised the provided in Section 406 of CPL rights of contesting a creditor's claim, equivalent consequence are to be established, the same as at all the other provided in the said Section undisputed events recognition of the commitment. In this regard, in order to prevent uncertainties in interpretation of the legal norm, the author proposes to amend Section 400 Paragraph One Clause 1 of CPL by plainly determining significance of proving the commitment to be transferred for undisputed enforcement in regard of the forms of public pledge (mortgage, commercial pledge).

\section{References}

[1] H. Kelsen, General Theory Of Law and State (Harvard University Press, CambridgeMassachusetts, 1945), p. 3

[2] K. Torgāns, Civilprocesa likuma komentāri. II Daļa. - Rīga: Tiesu namu ağentūra, 2012. - 632., 633., 635. lpp

[3] Latvijas Republikas Augstākās tiesas 2010.gada apkopojums par tiesu praksi saistību bezstrīdus piespiedu izpildǐ̌̌anā. - 3.-5. lpp

[4] Civilprocesa likums: LR likums. Latvijas Vēstnesis, 03.11.1998., Nr. 326/330

[5] Денисенко В.В. Легитимность как характеристика сущности права. Москва: Юрлитинформ, 2014. - стр. 40.-46

[6] C. Gusy, Legitimitaet im demokratischen Pluralismus. Stuttgart: Franz Steiner Verlag, 1987. - S. 9

[7] Latvijas Republikas Satversmes tiesas spriedums lietā Nr.2009-93-01 "Par Civilprocesa likuma 400. panta pirmās dalas 1. punkta un 405. panta pirmās un trešās daļas atbilstību Latvijas Republikas Satversmes 92. pantam” 4., 12.2., 13.4. tēze. 2010. gada 17. maijs. Latvijas Vēstnesis, 2010. gada 20.maijs, Nr. 79

[8] Сахнова Т. В. Курс гражданского прочесса: теоретические начала и основные институты. - Москва: Wolters Kluwer, 2008. - стр. 56.-59., 82.-86., 136. -138 
[9] Плешанов А. Г. Диспозитивное начало в сфере гражданской юрисдикции: проблемы теории и практики. - Москва: НОРМА, 2002. - стр. 19.-27., 58

[10] E. Kalniņš, Saistību tiesība (Vispārējs apskats), Likums un tiesības, 02.2011., 2(6), 48. lpp

[11] K. Canstein, K. Freiherr, Die rationallen Grundlagen des Civilprozesses. Berlin 1877. - S. 185.-198

[12] Schweizerische Zivilprozessordnung (Zivilprozessordnung, ZPO), Die Bundesversammlung der Schweizerischen Eidgenossenschaft, gestützt auf Artikel 122 Absatz 1 der Bundesverfassung, nach Einsicht in die Botschaft des Bundesrates vom 28. Juni 2006. Iegūts no: https://www.admin.ch/opc/de/ classified-compilation/20061121/201601010000/272.pdf (sk.14.04.2016.)

[13] H. Koziol, R. Welser, Grundriss des bürgerlichen Rechts. Band I. Allgemeiner Teil, Sachenrecht, Ffamilienrecht. Barbeitet von Andreas Kletečka. 13. Aufl. Wien: Manzsche Verlags - und Universitätsbuchhandlung, 2006. - S. 71

[14] K. Balodis, Ievads civiltiesībās. - Rīga: Zvaigzne ABC, 2007. - 117. lpp

[15] N. Horns, Ievads tiesību zinātnē un tiesību filosofijā, Likums un tiesības, 11.1999. 3, 73. $1 p p$

[16] Medicus, Dieter. Allgemeiner Teil des BGB. 8. Auf. Heidelberg: C.F. Müller Verlag, 2002. - Rn. 70

[17] K. Larenz, Wolf Manfred. Allgemeiner Teil des Bürgerlichen Rechts. 9. Aufl. München: Verlag C.H. Beck, 2004. - §14 Rn. 11

[18] V. Popova, Principles of Bulgarian Civil Procedure Law. Civil Procedure Review (ISSN 2191-1339), 2(2), 2011. - Pp. 36. Iegūts no: http://www.civil procedurereview.com/busca/baixa_ arquivo.php?id=38\&embedded=true (sk.01.12.2016.)

[19] J. Rozenfelds, Lietu tiesības. - Rīga: Zvaigzne ABC, 2011. - 188.-189. lpp

[20] Augstākās tiesas Senāta Civillietu departamenta 2012. gada 1. marta lēmums lietā Nr. SKC-1133/2012

[21] Augstākās tiesas Senāta Civillietu departamenta 2008. gada 9. janvāra lēmums lietā Nr. SPC-2

[22] R. Saulīte, Tiesu prakse pieteikumu izskatǐšanā par saistību bezstrīdus piespiedu izpildi, Juristu žurnāls, 1998; (8): 20. lpp

[23] Civillikums. Trešā dalı. Lietu tiesības: LR likums. Valdības Vēstnesis, 24.02.1937., Nr. 44

[24] Буковский В. Сводг гражданских узаконений губерний Прибалтиских св продолжением 1912.-1914. гг. и с разъяснениями в 2 томах. Том I. - Рига, 1914. - стр. 549

[25] G. Višņakova, K. Balodis, Latvijas Republikas Civillikuma komentāri. Lietas, valdījums, tiesības uz svešu lietu. - Rīga: Mans Īpašums, 1998. - 163., 222. lpp

[26] F. Konradi, A. Valters, Lietu tiesības. Baltijas Vietējo likumu kopojuma III dą̧as skaidrojumi. Rīga, 1935. - 381.-383. lpp

[27] Civillikums. Ceturtā daļa. Saistību tiesības: LR likums. Valdības Vēstnesis, 26.02.1937., Nr. 46

[28] Komercķīlas likums: LR likums. Latvijas Vēstnesis, 11.11.1998., Nr. 337/338

[29] Zivilprozessordnung. Ausfertigungsdatum: 12.09.1950. Zivilprozessordnung in der Fassung der Bekanntmachung vom 5. Dezember 2005 (BGB1. I S. 3202; 2006 I S. 431; 2007 I S. 1781). Iegūts no: https://www.gesetze-im-internet.de/englisch_ zpo/englisch_zpo.html (sk.15.02.2016.) 
[30] R. Braucher, German Civil Justice. - Durham, North Carolina: Carolina Academic Press, 2004. - Pp. 426

[31] H. Thomas, H. Putzo, K. Reichold, R. Hüßtege, Zivilprozeßordnung. C.H. Beck'sche Verlagsbuchhandlung. München, 1999. - S. 956.-957

[32] Гражданский процессуальный кодекс Российской Федерации. Принятие 23.10.2002., Государственная Дума, Вступление в силу $\mathrm{N}$ 138-Ф3 от 14.11.2002. Iegūts no: http://www. consultant.ru/document/cons_ doc LAW_ 39570/ (sk.14.04.2016.)

[33] Latvijas Republikas Satversmes tiesas spriedums lietā Nr.2008-04-01 "Par Civilprocesa likuma 441. panta otrās daļas (ciktāl tā attiecas uz lēmumu par naudas soda uzlikšanu procesuālās sankcijas veidā) atbilstību Latvijas Republikas Satversmes 92. pantam" 13.2. tēze. 2008. gada 5. novembris. Latvijas Vēstnesis, 2008. gada 11. novembris, Nr. 175

[34] P. Gottwald, Am. J. Comp. Law 31(4), 687 (1983)

[35] J.A. Jolowicz, On Civil Procedure (Cambridge University Press, Cambridge, 2000), pp. 3,71

[36] L.L. Teply, R.U. Whitten, Civil Procedure (The Foundation Press, Westbury, New York, 1994), p. 776

[37] N. Andrews, Principles of civil procedure (Sweet \& Maxwell, London, 1994), p. 21

[38] R.L. Marcus, M.H. Redish, E.F. Sherman, Civil Procedure, A Modern Approach, edited by St. Paul, 2nd edn. (West Publishing CO, 1995), p. 414 